\title{
A Preliminary Study on the Flipped Classroom Teaching Mode of Biochemistry
}

\author{
Weidong Xiao ${ }^{1,2}$, Guifang Chang ${ }^{1}$, Kexue $\mathrm{Yu}^{1}$, He Zhu¹, Yue An¹, \\ Yanxia Xing ${ }^{1, a}$, * \\ ${ }^{1}$ Department of Food Science and Engineering Shandong Agriculture and Engineering University, \\ Jinan 250100, China \\ 2 Jinan Licheng NO.2 High school, Jinan 250000, China \\ a, *603313136@qq.com
}

\begin{abstract}
With the advent of the information age, a new teaching mode of flipped classroom has emerged. This paper analyzes the current situation of biochemistry teaching in food specialty. In the process of exploring and practicing the flipped classroom teaching mode, local colleges and universities should carry out localized practice in combination with their own characteristics, and construct the flipped classroom teaching mode of the biochemistry by using the network refined product curriculum resources and the network communication software, and put forward the teaching effect evaluation suggestion.
\end{abstract}

Keywords: Flipped Classroom; Biochemistry; Mode.

\section{Introduction}

The advent of the information age has promoted the deep integration of information technology and education and teaching. The positioning of teachers and the role of learners have undergone great changes. Learners' learning methods have also gradually undergone fundamental changes and generated new teaching models, among which flipped classroom is a typical example.

In 2007, Jonathan bergman and Aaron sams, two chemistry teachers in woodland middle school, Colorado, United States, officially adopted the "flipped classroom teaching method", requiring students to learn by themselves the pre-recorded teaching video after class, and the classroom time was used to solve the problems encountered by students in the process of self-learning . This, in contrast to the traditional teacher in the Classroom during the day and students at home doing their homework at night, is called flipped Classroom. In July 2012, Flip Your Classroom: Talk to Every Student in Class Every Day, co-authored by bergman and sams, was published by the international educational technology association, and the flipped Classroom teaching theory was basically formed.

In China, especially in local undergraduate universities, the research and practice of flipped classroom have just started due to the constraints of education level, information technology and other software and hardware. In the process of exploration and practice of flipped classroom teaching model, local undergraduate colleges and universities should combine their own characteristics to carry out localization practice, instead of blindly pursuing and imitating the teaching models and teaching methods of developed countries in Europe and America [1] (such as massive development and construction of MOOCs platform and recording of MOOCs video, etc.).

"General biology" for food majors is a 45-hour science that studies life phenomena and their activity rules, including cytology, biochemistry, botany, zoology, heredity, evolution and other basic knowledge. This course has few class hours, rich content, wide coverage and other characteristics. Nowadays, college teaching is mainly "cramming" and "cramming", with a large number of abstract theories "going in one ear and out the other". Students do not have the opportunity to think actively in class and have no time to ask questions. This kind of teaching method often causes students to digest and absorb theoretical knowledge very hard. In the teaching process of general biology, we try to adopt the flipped classroom teaching mode to realize the transformation from "teaching" to "learning", study and explore new teaching mode, and solve the problems of "general biology" of food specialty with more teaching content and less class hours [2]. The teaching time of general 
biology is in the first semester of freshman year. Through flipped classroom, freshmen can exercise their independent learning ability, so that they can better adapt to university learning [3].

\section{Construction of Flipped Classroom Teaching Model of General Biology}

\subsection{Establishment of Communication Platform}

QQ group is a favorite communication platform for college students at present. It can upload various teaching resources and add the whole class into a group. Learning on such a platform can not only arouse students' interest in learning, but also promote the communication between students and students and between students and teachers.

\subsection{According to the Syllabus, Arrange the Teaching Content}

Food general biology teaching content is different from other ordinary biology teaching content, should not only consider the whole course of systemic and integrity, and want to consider the particularity of food profession, are associated with subsequent courses and teaching content does not repeat, the general biology teaching content is divided into five modules: cell biology, animal biology, plant biology, genetic variation, biodiversity, etc. [4].

\subsection{Establish Abundant Pre-Class Teaching Resources}

The teaching of flipped classroom transfers traditional knowledge teaching from classroom to preclass, and the preparation of teaching materials before class is particularly important. Considering the actual situation of local undergraduate colleges and universities, they cannot develop and build a large number of MOOCs platforms and record MOOCs video as the European and American countries or domestic key undergraduate colleges and universities. There are many free national and provincial quality courses on the Internet, and local undergraduate colleges can make full use of rich network resources [5].

\subsubsection{Sorting out Teaching Materials before Class}

According to the teaching content of the five modules, we refer to and sort out the teaching resources of other universities, including teaching outline, teaching plan, teaching PPT, video, relevant learning websites and other teaching materials. Each large module is further divided into several small modules, and each module is allocated corresponding credit hours. Such as cell biology this part can be divided into three small modules such as cell structure, cell communication, cell division and differentiation [6]. Each module makes a teaching guide plan, including teaching objectives, teaching content (teaching plan, teaching PPT, micro video), pre-class exercises, etc. The teaching objective enables students to understand what content to master and what content to understand through the learning of this module. Teaching PPT shows the teaching contents involved in this module to students. Students can learn independently through teaching plan and PPT in combination with teaching materials. About biology involved in some of the words describing the content of the difficult solution, such as the three structure system in eukaryotic cell, signal transduction, animal cell mitosis, etc., may be a small video, dynamic show students the life process, fully attract students' attention, increase students' learning interest, make students easier to understand mechanism of life. In addition to biological animation, micro-video can record micro-video in advance for some key and difficult points of teaching. These video times are about 10 minutes, and only the key and difficult points of teaching content can be explained $[7,8]$.

\subsubsection{Targeted Teaching Exercises}

Students can test the effect of self-study by practicing before class. According to the level of students, teachers can reasonably design a number of pre-class exercises, which include both basic knowledge points and teaching key and difficult points. The questions are challenging to stimulate students' interest in learning. At the same time, the teacher should ask the students to complete the exercise within a certain period of time to confirm whether the students have mastered the teaching 
content of the module. The test can be conducted in the form of online grading to timely grasp the learning situation of the students $[9,10]$.

\subsubsection{Communication Feedbacks}

In the process of learning before class, students should not only complete the teaching content and teaching practice assigned by the teacher, but also timely record their problems encountered in the learning process, and give feedback to the teacher through QQ in a timely manner. In view of the questions raised by students, teachers can answer individual questions individually, and analyze and summarize the general questions raised by students in combination with the practice before class, so as to prepare for class discussion.

\subsection{Class Discussion}

\subsubsection{Determine the Questions to Discuss in Class}

According to the feedback of students' independent learning, teachers determine some problems that are difficult for students to understand and worth exploring. For example, the small module of central vascular system of animal biology module, after self-study, students can easily master some knowledge of cardiovascular structure, while the pumping process of the heart is not very clear, and the pumping process can be used as a problem for further discussion.

\subsubsection{Group Study, Communication and Interaction}

When collaborative learning and interaction problems are determined, the teacher does not directly explain them. Instead, the whole class is divided into several groups, and discussions are conducted among group members or even among groups, so as to internalize knowledge, improve students' problem-solving ability and enhance team spirit.

\subsubsection{Display and Exchange of Results}

After the group discussion, the results should be presented timely. Each group can elect a representative to present the results of the group discussion to everyone through PPT and other forms. Members of other groups can put forward their own ideas. Through the demonstration of the results, students can deepen their understanding of the important and difficult points and increase their ability to analyze and express the problems.

\subsubsection{The Role of Teachers}

The role of teachers in the process of classroom discussion is mainly to control the whole classroom atmosphere, to give timely analysis and evaluation to students in the process of showing results, to affirm students' results, but also to point out the existing problems. After the completion of a module learning, the teacher should timely summarize the students' learning situation, comb the knowledge points, expand and extend the knowledge points, and let the students complete the knowledge in the process of summary, reflection and evaluation construction .

\subsection{After-class Teaching Design}

After class, students should learn the teaching contents that they did not understand by themselves before class. After class discussion and teacher guidance, students should timely sort out and summarize the learning contents, and ask students to record them in the form of notes to deepen their understanding of knowledge.

\section{Design for Experiments}

\subsection{Preparation before Shooting}

First, the theme and type of micro-lessons should be determined according to teaching needs. In the micro-course construction of "food microbiology experiment", we mainly designed three types of knowledge teaching, experimental operation and expanding innovation. Knowledge teaching type, such as "dye type and selection" (micro class name, the same after) and "food microbiological test 
sample processing"; Experimental procedures such as "simple staining of bacteria" and "wrapping of glassware"; Expand innovation such as "factors affecting gram's staining results" and "is it negative? Will silk come out?" Then, according to the theme, it was determined that micro lectures were mainly manifested in three types: experimental operation (such as "inverting plate technology"), PPT recording screen (such as "method of melting culture medium"), experimental operation + PPT recording screen (such as "construction of ordinary optical microscope"). Before shooting, prepare strains, microscopes, sterile petri dishes and staining solution, etc.

\subsection{Experimental Operation and Shooting}

When shooting experimental operation, ensure sufficient light (choose sunny weather as far as possible) and avoid stroboscopic phenomenon when there is indoor light. The shooting equipment should be stable without shaking. Look for the right Angle to take the shot, ensuring that the operator's body parts do not block out the lens, that the materials needed for the operation are included in the lens (e.g. "mold morphology observation"), and that the details of the operation are well displayed (e.g. "bevel inoculation technique"). Depending on the situation, the lens Angle can be changed during the shooting process (e.g. "use of pressurized steam sterilizer"). Use gestures to introduce equipment and reagents (e.g. "aseptic smear technique"). According to teaching requirements, objects can be moved in front of the lens during operation to make it clearer (e.g. "wrapping of the triangular bottle"), but be careful to keep an appropriate distance from the lens and not to move out of the lens. As for whether to explain while operating, or not, and to add explanation during later video processing, the author concluded after many practices that the latter would make the shooting process more efficient and the interpretation of the voice more stable (such as "the use of oil mirror of optical microscope").

\subsection{Editing and Processing after Shooting}

After shooting, video can use Camtasia Studio software to cut out unnecessary pictures and eliminate noise. In general, the waiting process in experimental operation needs to be deleted, and only need to explain with words. For particularly error-prone details, zoom in or zoom out (e.g. "Is it negative? Will silk come out?"), add arrow symbols in later video processing (such as "structure of desktop automatic fermentation tank"), add text beside it (such as "inverted plate technology"), and add animation demonstration (such as "plate marking technology"). After the video clip is completed, add the explanation of experimental operation. Add subtitles in key operations, rare words or places that are likely to cause confusion of speech and hearing (e.g. "spore staining"). If it is in the form of "experimental operation + recording PPT screen", it is still necessary to integrate the PPT screen after recording with the experimental operation video completed by editing and then add the title, end and background music to complete a micro-lesson video.

\section{Build an Information-based Learning Platform}

Micro-courses are designed for online learning. Therefore, with micro-courses, online learning platform is also needed. We have set up the course website of "food microbiology experiment" on the platform of the course center of Suzhou University. The website is beautifully designed, rich in content and distinctive in features.

Become the important platform of knowledge dissemination of this course. In terms of content, there are not only 31 micro-lectures, but also other abundant learning materials. In addition, the course website also provides us with a large amount of data on students' learning behavior, which not only plays an effective supervision on students' independent learning before class.

Supervision and management function also provides reference for us to further deepen the teaching reform in the future. The course website and micro-course also specially implement mobile APP application, as shown in figure 1. At present, the campus of Soochow University has achieved full Wi-Fi coverage, so the mobile phone APP is very popular with students as soon as it is launched. Students simply click on the desktop of the phone. APP can be used for learning, which is convenient, 
fast and efficient. Full screen display function when watching, to bring students a pleasant learning experience.

Under the traditional teaching mode, the biggest difficulty for students outside the classroom is that they cannot get timely guidance from the teacher when they encounter problems. Therefore, it is the students' biggest appeal to get help and clarification at any time. Therefore, in addition to the interactive discussion area on the course website, we also have a more convenient and fast course QQ group and We Chat group, students at any time, as long as there are ideas, questions, needs, can through the above various channels for teacher-student interaction and student interaction. In addition, these interactive platforms also provide space for after-school teacher comments and student evaluations.

\section{Conclusion}

Based on the micro-course construction of "food microbiology" [5] and applied research, the author explored and practiced the teaching reform of experimental courses. In this study, we independently designed, filmed and made 31 micro-lectures that met the teaching content and teaching requirements of "food microbiology experiment" in Suzhou University. They become popular learning materials for students and free teachers from repetitive work. Flip in class based on classroom practice, we've come to the conclusion that the "one, two, three, four imitation, five evaluation" teaching strategies and implement the "give priority to in order to teach" turn "give priority to in order to learn" and "classroom teaching" to "class inside and outside combination", "knowledge teaching" to "ability", make the students' self-control ability, learning ability, practical ability and cooperative ability such as the comprehensive exercise.

\section{References}

[1]. DOOLEY L M, S F, E B, et al. Implementing the Flipped Classroom in a Veterinary Pre-clinical Science Course: Student Engagement, Performance, and Satisfaction [J]. Journal of Veterinary Medical Education, 45 (2): 195.

[2]. MOFFETT J, MILL A C. Evaluation of the flipped classroom approach in a veterinary professional skills course [J]. 2014, 2014 (default): 415-425.

[3]. ELMAADAWAY, NAGY M A. The effects of a flipped classroom approach on class engagement and skill performance in a blackboard course [J]. British Journal of Educational Technology.

[4]. MCLAUGHLin J E, ROTH M T, GLATT D M, et al. The Flipped Classroom: A Course Redesign to Foster Learning and Engagement in a Health Professions School [J]. Academic medicine: journal of the Association of American Medical Colleges, 2013, 89 (2): 236-243.

[5]. GROSS D, PIETRI E S, ANDERSON G, et al. Increased Preclass Preparation Underlies Student Outcome Improvement in the Flipped Classroom [J]. CBE life sciences education, 2015, 14 (4): ar36.

[6]. MOORING S R, MITCHELL C E, BURROWS N L. Evaluation of a Flipped, Large-Enrollment Organic Chemistry Course on Student Attitude and Achievement [J]. Journal of Chemical Education, acs.jchemed.6b00367.

[7]. ADAMSON B, H K. The Impact of an Integrated Math and Science Curriculum on Third Grade Students' Measurement Achievement [J]. 2008.

[8]. HERNáNDEZ A C. The Professional Development of Pre-service Teachers in an Integrated Science and Language Acquisition Curriculum with Third-Grade Students [M]. 2017. 
[9]. LEE R L T, WONG T K S, ALGASSEER N, et al. Evaluating the efficacy of an integrated curriculum on adolescent health and development for pre-service nursing education in Hong Kong [J]. 2006, 26 (4): 286-297.

[10]. WILLIAMS B G. An Evaluation of a Continuous Progress Plan in Reading and Mathematics on the Achievement and Attitude of Fourth, Fifth, and Sixth Grade Pupils [J]. 1973. 